Huixiang Yu*, Xinhua Wang, Jing Zhang and Wanjun Wang

\title{
Laboratory Study on Oxide Inclusions in High-Strength Low-Alloyed Steel Refined by Slag with Basicity 2-5
}

\begin{abstract}
Non-metallic inclusions in high-strength lowalloyed steel refined by slag with basicity $(B) 2-5$ and $\mathrm{Al}_{2} \mathrm{O}_{3}$ content $20 \%-30 \%$ (in mass percent) were investigated by slag-metal equilibrium experiments in laboratory and thermodynamic calculations. Most inclusions in equilibrium were quasi-spherical $\mathrm{CaO}-\mathrm{MgO}-\mathrm{Al}_{2} \mathrm{O}_{3}-\mathrm{SiO}_{2}$ system and the sizes were less than $5 \mu \mathrm{m}$. The average content ratio, $\mathrm{CaO} / \mathrm{Al}_{2} \mathrm{O}_{3}$ and $\mathrm{CaO} / \mathrm{SiO}_{2}$ of the inclusions, increased with slag basicity increasing when $\mathrm{Al}_{2} \mathrm{O}_{3}$ content in slag was around $25 \%, \mathrm{MgO} / \mathrm{Al}_{2} \mathrm{O}_{3}$ and $\mathrm{CaO} / \mathrm{Al}_{2} \mathrm{O}_{3}$ increased with $\mathrm{Al}_{2} \mathrm{O}_{3}$ content in slag decreasing when slag basicity was around 3.3. The $\mathrm{MgO} / \mathrm{Al}_{2} \mathrm{O}_{3}$ of the inclusions was influenced mainly by $\mathrm{Al}_{2} \mathrm{O}_{3}$ content in slag and $\mathrm{CaO} / \mathrm{Al}_{2} \mathrm{O}_{3}$ was influenced mainly by slag basicity. To make the inclusions out of relative lower melting region $(<1,773 \mathrm{~K})$, the values of $\mathrm{CaO} / \mathrm{Al}_{2} \mathrm{O}_{3}, \mathrm{MgO} / \mathrm{Al}_{2} \mathrm{O}_{3}$ and $(\mathrm{CaO}+\mathrm{MgO}) / \mathrm{Al}_{2} \mathrm{O}_{3}$ of the inclusions should be enhanced by increasing basicity and decreasing $\mathrm{Al}_{2} \mathrm{O}_{3}$ content in slag properly.
\end{abstract}

Keywords: HSLA steel, oxide inclusions, refining slag, basicity, $\mathrm{Al}_{2} \mathrm{O}_{3}$ content

PACS number: $81.05 . \mathrm{Bx}$

DOI 10.1515/htmp-2014-0116

Received July 1, 2014; accepted October 9, 2014

\footnotetext{
*Corresponding author: Huixiang Yu, State Key Laboratory of Advanced Metallurgy, University of Science and Technology Beijing, Beijing 100083, China; School of Metallurgical and Ecological Engineering, University of Science and Technology Beijing, Beijing 100083, China, E-mail: yuhuixiang@ustb.edu.cn Xinhua Wang, School of Metallurgical and Ecological Engineering, University of Science and Technology Beijing, Beijing 100083, China, E-mail: wangxinhua@ustb.edu.cn Jing Zhang, Wide Plate and Coil Plant, Nanjing Iron and Steel Co. Ltd., Nanjing 210035, Jiangsu, China,

E-mail: zhangjingzi666@163.com

Wanjun Wang, School of Metallurgical and Ecological Engineering, University of Science and Technology Beijing, Beijing 100083, China, E-mail: wangwanjun@metall.ustb.edu.cn
}

\section{Introduction}

High-strength low-alloyed (HSLA) steel plates are widely used in shipbuilding and offshore platform and are strictly required for strength, low-temperature toughness and ductility properties. HSLA steels are usually Al-killed and refined by slag of high basicity $\left(B=\% \mathrm{CaO} / \% \mathrm{SiO}_{2}\right.$, in mass percent) and containing high $\mathrm{Al}_{2} \mathrm{O}_{3}$ content [1-4]. As a result, inclusions of $\mathrm{MgO}-\mathrm{Al}_{2} \mathrm{O}_{3}-\mathrm{CaO}, \mathrm{CaO}-\mathrm{Al}_{2} \mathrm{O}_{3}$ and CaO-CaS- $\mathrm{Al}_{2} \mathrm{O}_{3}$ system are usually formed including calcium aluminates with low melting temperature, such as $12 \mathrm{CaO} \cdot 7 \mathrm{Al}_{2} \mathrm{O}_{3}$ and $\mathrm{CaO} \cdot \mathrm{Al}_{2} \mathrm{O}_{3}[5,6]$. Inclusions with low melting point can be elongated to stringers during subsequent rolling, which are the main reason that deteriorate the properties of ductility, anti-hydrogen-induced cracking and anti-stress corrosion cracking of the steel plates [7, 8]. The detrimental effect of inclusions becomes more apparent with increasing strength level of HSLA steel.

Wang et al. and Son et al. studied the transformation of inclusions in steel during aluminum deoxidation process as well as the refining process with high basicity and $\mathrm{Al}_{2} \mathrm{O}_{3}$-bearing slags $[5-7,9,10]$. During these processes, $\mathrm{MgO}$ and $\mathrm{CaO}$ in slag and ladle refractory can be reduced by the dissolved aluminum in the molten steel, resulting in the pick-up of $[\mathrm{Mg}]$ and $[\mathrm{Ca}]$ in the steel to several mass ppm, so that deoxidation products of $\mathrm{Al}_{2} \mathrm{O}_{3}$ gradually change to inclusions of $\mathrm{MgO}-\mathrm{Al}_{2} \mathrm{O}_{3}, \mathrm{MgO}-\mathrm{Al}_{2} \mathrm{O}_{3}-\mathrm{CaO}$ or $\mathrm{CaO}-\mathrm{Al}_{2} \mathrm{O}_{3}$.

Researches on the effect of refining slag on inclusions in equilibrium have been reported. Slags refined with $<2$ basicity and $<20 \% \quad \mathrm{Al}_{2} \mathrm{O}_{3}$ were reported by Wang et al. and Jiang et al. [11-13]. Chen and Jiang et al. investigated the effect of high basicity and $\mathrm{Al}_{2} \mathrm{O}_{3}$ content $\left(B=8, \mathrm{Al}_{2} \mathrm{O}_{3} \geq 35 \%\right)$, and studied inclusions in $0.6 \% \mathrm{C}-1.5 \% \mathrm{Si}-0.8 \% \mathrm{Mn}$ steel refined by slags with basicity 3.5 and containing $25 \% \mathrm{Al}_{2} \mathrm{O}_{3}$ as well as those in 0.4\%C-0.25\%Si-0.65\%Mn-1.1\%Cr-0.2Mo steel under slag with basicity 5 and containing $25 \% \mathrm{Al}_{2} \mathrm{O}_{3}$ [14-16]. They reported that inclusions in equilibrium with these slags were mainly $\mathrm{MnO}-\mathrm{SiO}_{2}-\mathrm{Al}_{2} \mathrm{O}_{3}-\mathrm{CaO}$ and $\mathrm{CaO}-\mathrm{MgO}-\mathrm{Al}_{2} \mathrm{O}_{3}$ $\mathrm{SiO}_{2}$ with low melting point; inclusions in the steel 
refined with 3.5 or 5 basicity and $25 \% \mathrm{Al}_{2} \mathrm{O}_{3}$ slag contained more $\mathrm{MgO}$ and had relatively higher melting temperature.

Very few researches were reported that studied inclusions in HSLA steel refined by $2-5$ basicity slag, and whether calcium aluminate inclusions with low melting point can be effectively lowered by the refining slag with relative lower basicity and $\mathrm{Al}_{2} \mathrm{O}_{3}$ content was rarely reported. For this reason, the current paper investigates inclusions in HSLA steel refined by the slag with 2-5 basicity and $20 \%-30 \% \quad \mathrm{Al}_{2} \mathrm{O}_{3}$ using slag-metal equilibrium experiments.

\section{Experiment}

A vertical Si-Mo-heated high-temperature furnace was used for the equilibrium experiments between the metal and slag. Two hundred grams steel (0.045 mass\% C, 0.19 mass $\% \mathrm{Si}, 1.8$ mass $\% \mathrm{Mn}$ ) and $40 \mathrm{~g}$ slag were melted together in $\mathrm{MgO}$ crucibles at 1,873 $\mathrm{K}$ under argon-protective atmosphere. During the experiments, 99.999\% purity Ar gas was introduced into the reaction tube at a constant flow rate of $1.5 \mathrm{~L} / \mathrm{min}$. The slag was made by mixing reagent-grade $\mathrm{CaO}, \mathrm{Al}_{2} \mathrm{O}_{3}, \mathrm{SiO}_{2}$ and $\mathrm{MgO}$ oxide powder in proportion together. The slag composition before experiments is shown in Table 1 . Ninety minutes was needed to reach slag-metal equilibrium under $1,873 \mathrm{~K}$, so that all experiments were performed for 90 minutes under $1,873 \mathrm{~K}$ without stirring to float inclusions out and establish equilibrium, and then the crucible was taken out from the furnace and quenched rapidly in water.

Table 1: Original chemical composition of slags, mass $\%$.

\begin{tabular}{lcrr}
\hline Slag No. & $\boldsymbol{B}\left(\mathrm{CaO} / \mathbf{S i O}_{\mathbf{2}}\right)$ & $\mathbf{A l}_{\mathbf{2}} \mathbf{O}_{\mathbf{3}}$ & $\mathbf{M g 0}$ \\
\hline 1 & 2 & 25 & 11 \\
2 & 3.5 & 25 & 7 \\
3 & 5 & 25 & 6 \\
4 & 3.5 & 20 & 6 \\
5 & 3.5 & 30 & 8 \\
\hline
\end{tabular}

The contents of silicon, manganese and phosphorus in steel sample were analyzed by inductively coupled plasma atomic emission spectroscopy (ICP-AES), and carbon and sulfur by infrared absorption method. The contents of $\mathrm{CaO}, \mathrm{MgO}, \mathrm{Al}_{2} \mathrm{O}_{3}$ and $\mathrm{MnO}$ in slag sample were analyzed by ICP-AES, FeO by titration method and $\mathrm{SiO}_{2}$ by gravimetric method. Thirty-five points on the cross- sectioned plane of each steel sample were randomly chosen to detect inclusions by scanning electron microscope and energy-dispersive $\mathrm{x}$-ray spectrometer (EDS) to get statistical information of inclusions including morphology, size and chemical composition.

The effect of slag basicity and $\mathrm{Al}_{2} \mathrm{O}_{3}$ content in the slag on inclusions was investigated. As shown in Table 1 , the basicity levels of 2, 3.5 and 5 with $25 \% \mathrm{Al}_{2} \mathrm{O}_{3}$ were chosen to study the effect of basicity. The $\mathrm{Al}_{2} \mathrm{O}_{3}$ levels of $20 \%, 25 \%$ and $30 \%$ with 3.5 slag basicity were chosen to study the effect of $\mathrm{Al}_{2} \mathrm{O}_{3}$ content. $\mathrm{MgO}$ was added to the slag at a saturated level that was predicted by thermodynamic software Thermo-Calc.

Before equilibrium experiments, pre-equilibrium experiments were performed to decide the time to reach slag-steel equilibrium for the slag with 3.5 basicity, and containing $25 \% \mathrm{Al}_{2} \mathrm{O}_{3}$ and saturated $\mathrm{MgO}$ under $1,873 \mathrm{~K}$. In previous investigations [9, 14-16], 90-120 minutes was always considered as the holding time for the equilibrium experiments between steel and top slag. In the present work, three holding times of 90, 90 and 120 minutes were chosen to decide the time for equilibrium and study the repeatability of equilibrium experiments under the current conditions.

\section{Results}

\section{Pre-equilibrium experiments}

The chemical composition of steel and slag samples of the three heats, with holding times of 90, 90 and 120 minutes, respectively, after equilibrium is shown in Tables 2 and 3, showing similar composition and low sulfur content for the three heats.

Table 2: Chemical composition of steel samples, mass $\%$.

\begin{tabular}{lrrrrr}
\hline Heat No. & C & Si & Mn & P & S \\
\hline 1 & 0.044 & 0.18 & 1.77 & 0.0070 & 0.0004 \\
2 & 0.041 & 0.18 & 1.78 & 0.0080 & 0.0003 \\
3 & 0.040 & 0.17 & 1.78 & 0.0070 & 0.0003 \\
\hline
\end{tabular}

Table 3: Chemical composition of slag samples, mass $\%$.

\begin{tabular}{lrlllllllr}
\hline $\begin{array}{l}\text { Heat } \\
\text { No. }\end{array}$ & $\mathrm{CaO}$ & $\mathbf{M g O}$ & $\mathrm{SiO}_{2}$ & $\mathrm{Al}_{2} \mathbf{O}_{3}$ & $\mathrm{MnO}$ & $\mathrm{FeO}$ & $\mathrm{S}$ & $\begin{array}{r}\% \mathrm{CaO} / \% \\
\mathrm{SiO}_{2}\end{array}$ \\
\hline 1 & 49.63 & 8.74 & 15.26 & 24.8 & 0.19 & $<0.1$ & 0.015 & 3.25 \\
2 & 50.21 & 8.66 & 15.39 & 25 & 0.18 & $<0.1$ & 0.016 & 3.26 \\
3 & 50.11 & 9.04 & 15.31 & 25.03 & 0.18 & $<0.1$ & 0.017 & 3.27 \\
\hline
\end{tabular}




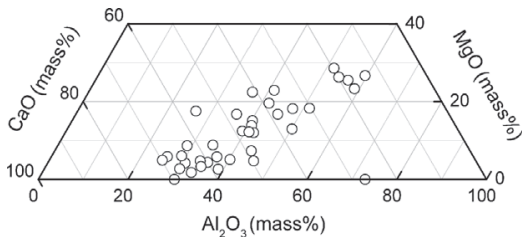

(a)

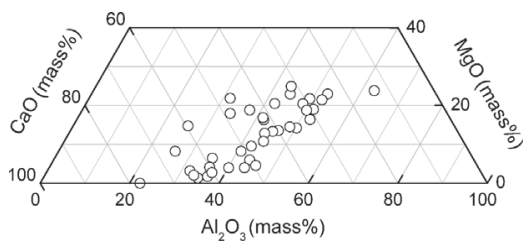

(b)

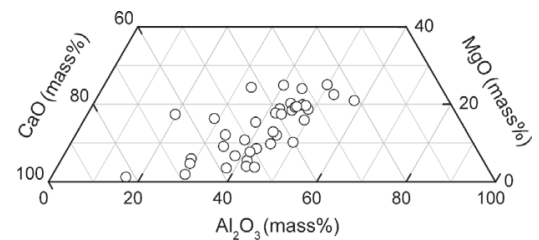

(c)

Figure 1: Composition distribution of inclusions in steel samples of pre-equilibrium experiments. (a) 90 min holding; (b) 90 min holding; (c) 120 min holding.

The EDS detection indicated that inclusions in steel for the three heats mainly contained $\mathrm{CaO}, \mathrm{Al}_{2} \mathrm{O}_{3}, \mathrm{MgO}$ and approximately $11 \% \mathrm{SiO}_{2}$ as shown in Figure 1 . It can be seen that the composition distribution of inclusions of the three heats had little difference.

Since the composition of steel, slag and inclusions for the three heats was approximately identical, the equilibrium can be reached after 90 minutes under the present experimental conditions, and the results showed good repeatability. Thus, the reaction time for the following experiments was set to 90 minutes.

\section{Equilibrium experiments}

The chemical composition of steel samples after equilibrium under the five slag conditions is shown in Table 4 and the chemical composition of the slag samples after equilibrium is listed in Table 5. Low contents of $\mathrm{MnO}$ and $\mathrm{FeO}$ suggest that the reduced atmosphere in the reaction tube was controlled well. For the slag conditions No. 1, 2 and 3 (Table 1 ), the basicity was $1.93,3.26$ and 4.54 , respectively, after equilibrium, and $\mathrm{Al}_{2} \mathrm{O}_{3}$ content was similarly 24\%-26\%. For the slag conditions No. 4, 2 and 5 (Table 1), the $\mathrm{Al}_{2} \mathrm{O}_{3}$ content in the slag was about $21 \%, 25 \%$ and $30 \%$, respectively, after equilibrium, and slag basicity after equilibrium was fixed at approximately 3.3.

The typical morphology and corresponding EDS of inclusions in the steel samples equilibrated with slag No. 1-5 are shown in Figure 2(a)-(e), respectively, indicating spherical shape and $<5 \mu \mathrm{m}$ size. The boundaries of inclusions under slag No. 3 and 4 conditions are less smooth than those under slag No. 1, 2 and 5 conditions.
Table 5: Chemical composition of slag samples, mass\%.

\begin{tabular}{lrlrll}
\hline Slag No. & $\boldsymbol{B}\left(\mathrm{CaO} / \mathrm{SiO}_{2}\right)$ & $\mathrm{Al}_{\mathbf{2}} \mathbf{O}_{\mathbf{3}}$ & $\mathrm{MgO}$ & $\mathrm{MnO}$ & $\mathrm{FeO}$ \\
\hline 1 & 1.93 & 24.48 & 13.65 & 0.34 & $<0.1$ \\
2 & 3.26 & 25 & 8.66 & 0.18 & $<0.1$ \\
3 & 4.54 & 26.12 & 9.56 & 0.16 & $<0.1$ \\
4 & 3.27 & 21.22 & 9.76 & 0.2 & $<0.1$ \\
5 & 3.31 & 30.04 & 10.19 & 0.17 & $<0.1$ \\
\hline
\end{tabular}

Most inclusions in steel samples after equilibrium were CaO-MgO- $\mathrm{Al}_{2} \mathrm{O}_{3}-\mathrm{SiO}_{2}$ system, and $\mathrm{SiO}_{2}$ content in inclusions was relative stable for each slag condition but varied with slag basicity, as shown in Figure 3, where the liquid regions of different temperature calculated using thermodynamic software Factsage are also plotted. For slag No. 1, 2 and 3 which had different basicity but identical $\mathrm{Al}_{2} \mathrm{O}_{3}$ content, the average $\mathrm{SiO}_{2}$ content in inclusions in equilibrium was $22 \%, 11 \%$ and $9 \%$, respectively. The dots in Figure 3 represent the composition of separate inclusions and the stars are the average values. The curved regions stand for the liquid zones of different temperature in Celsius degree.

With the decrease of $\mathrm{SiO}_{2}$ content in $\mathrm{CaO}-\mathrm{MgO}-\mathrm{Al}_{2} \mathrm{O}_{3}$ $\mathrm{SiO}_{2}$ system, the liquid zone $(<1,773 \mathrm{~K})$ moved toward the direction of $(\mathrm{CaO}+\mathrm{MgO}) / \mathrm{Al}_{2} \mathrm{O}_{3}$ and decreases. The $\mathrm{SiO}_{2}$ content in inclusions decreased with the rise of slag basicity and $(\mathrm{CaO}+\mathrm{MgO})$ content increased. The inclusions were mainly liquid $(<1,773 \mathrm{~K})$ when the slag basicity was 1.93 or 3.26 , while some inclusions entered higher temperature region $(\geq 1,773 \mathrm{~K})$ when the slag basicity was 4.54 .

For slags No. 4, 2 and 5 which had different $\mathrm{Al}_{2} \mathrm{O}_{3}$ content but identical basicity of 3.3, the average $\mathrm{SiO}_{2}$

Table 4: Chemical composition of steel samples, mass\%.

\begin{tabular}{lrrrrr}
\hline Composition & C & Si & Mn & P & S \\
\hline Concentration & $0.041-0.048$ & $0.17-0.19$ & $1.76-1.82$ & $0.0065-0.0082$ & $0.0003-0.0010$ \\
\hline
\end{tabular}



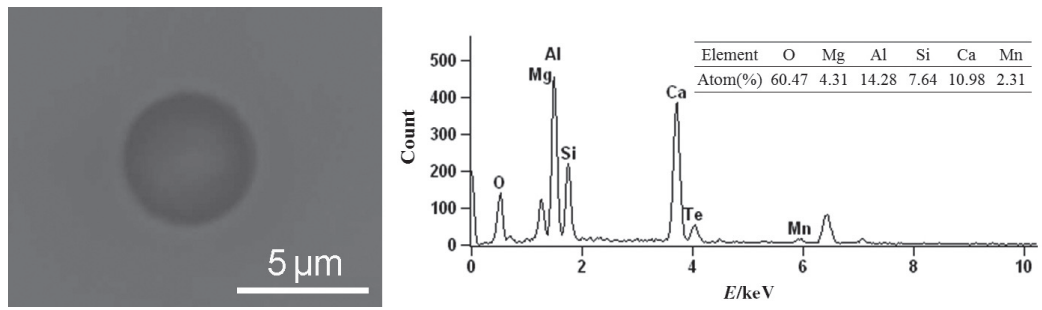

(a)
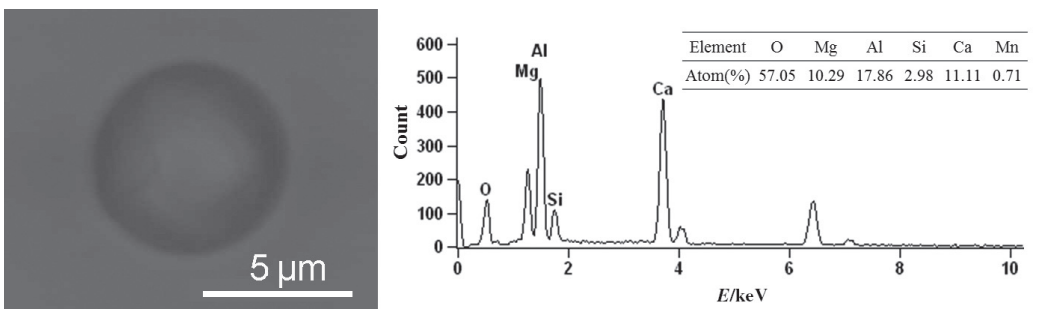

(b)
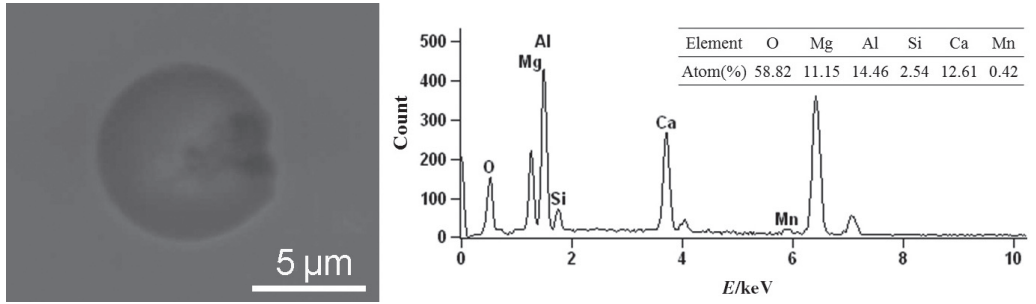

(c)
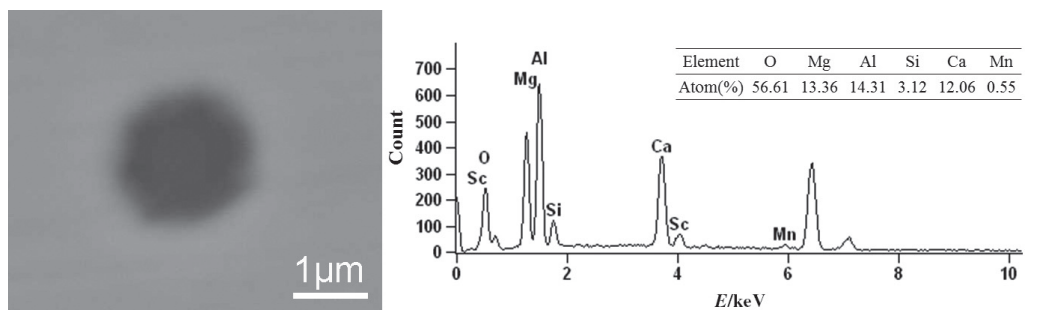

(d)
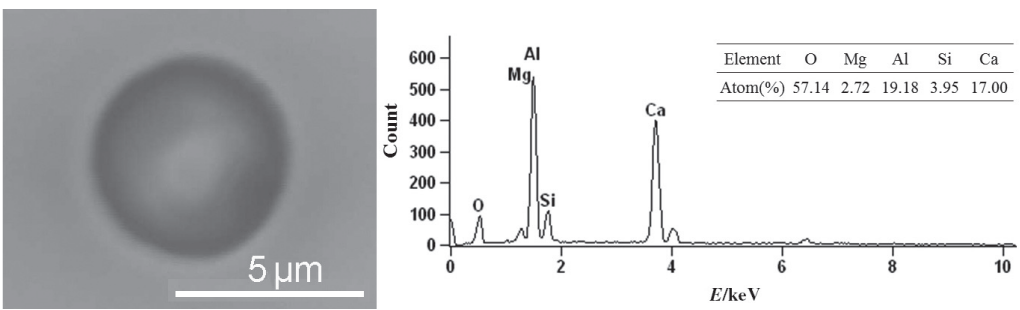

(e)

Figure 2: Typical morphology and EDS of inclusions detected in steel samples under slag No. 1-5. (a) Slag No. 1; (b) slag No. 2; (c) slag No. 3; (d) slag No. 4; (e) slag No. 5.

content in inclusions in equilibrium was approximately $11 \%$ as shown in Figure 4.

The inclusions under slag No. 4 condition were significantly different from those under slag No. 2 and 5 . Most inclusions were liquid $(<1,773 \mathrm{~K})$ when $\mathrm{Al}_{2} \mathrm{O}_{3}$ in slag was about $25 \%$ or $30 \%$, while many inclusions were solid $(\geq 1,773 \mathrm{~K})$ when $\mathrm{Al}_{2} \mathrm{O}_{3}$ was about $21 \%$.

\section{Discussion}

\section{Effect of slag basicity on inclusions}

The ratios of components' average content in inclusions, $\mathrm{CaO} / \mathrm{Al}_{2} \mathrm{O}_{3}, \mathrm{MgO} / \mathrm{Al}_{2} \mathrm{O}_{3}$ and $\mathrm{CaO} / \mathrm{SiO}_{2}$, under different 


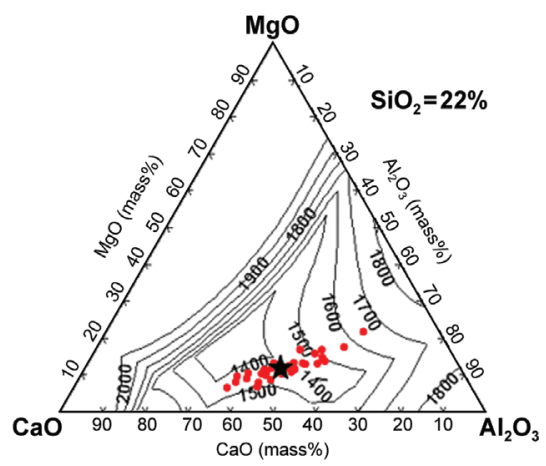

(a)

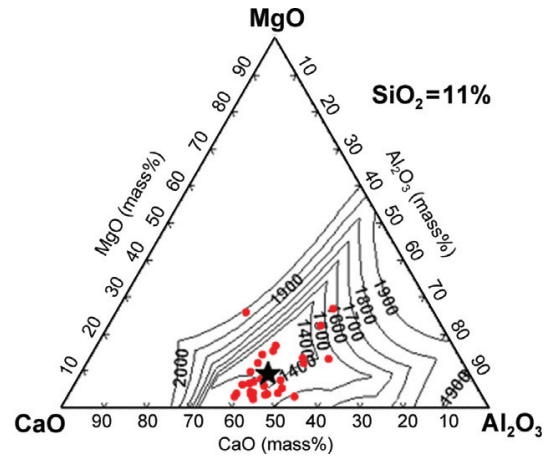

(b)

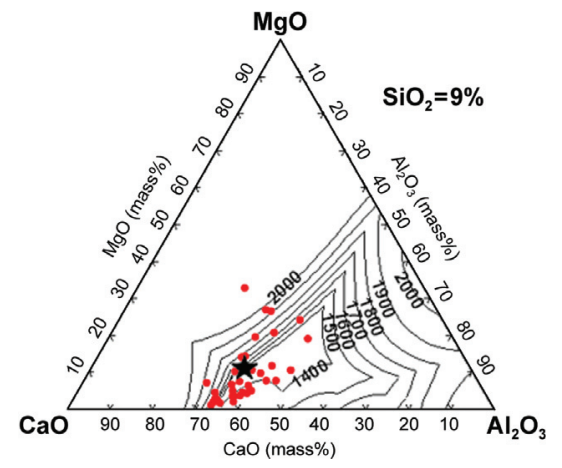

(c)

Figure 3: Composition distribution of inclusions under different basicity slag conditions. (a) Slag No. 1 (B: 1.93); (b) slag No. 2 (B: 3.26 ); (c) slag No. 3 (B: 4.54).

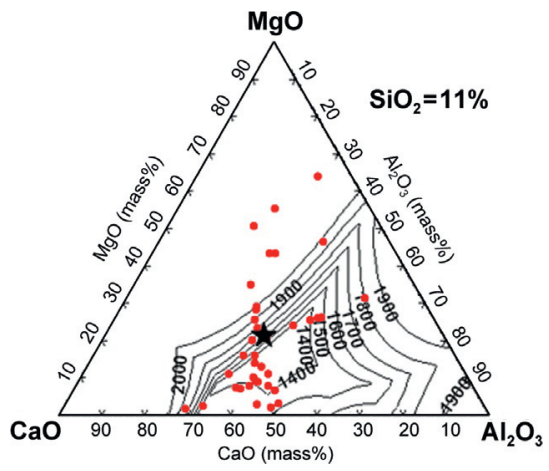

(a)

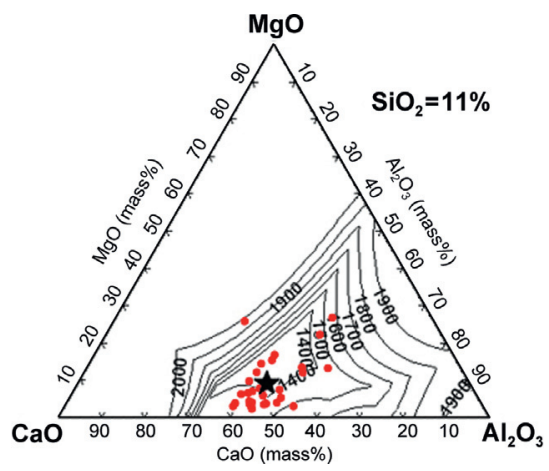

(b)

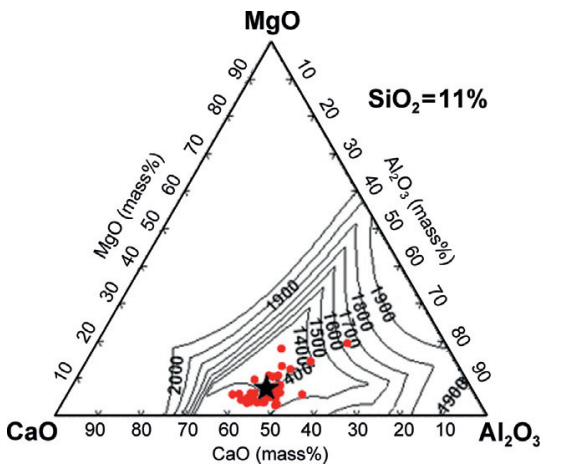

(c)

Figure 4: Composition distribution of inclusions under different $\mathrm{Al}_{2} \mathrm{O}_{3}$ slags. (a) Slag No. $4\left(\mathrm{Al}_{2} \mathrm{O}_{3}: 21.22 \%\right)$; (b) slag No. 2 ( $\mathrm{Al}_{2} \mathrm{O}_{3}: 25 \%$ ); (c) slag No. $5\left(\mathrm{Al}_{2} \mathrm{O}_{3}: 30.04 \%\right)$.

basicity slag conditions are shown in Figure 5 . With the rise of slag basicity but identical $\mathrm{Al}_{2} \mathrm{O}_{3}$ content, the $\mathrm{CaO} /$ $\mathrm{SiO}_{2}$ of inclusions increased sharply with values of 1.39 , 3.89 and 5.77, $\mathrm{CaO} / \mathrm{Al}_{2} \mathrm{O}_{3}$ increased with values of 0.93 , 1.08 and 1.42 and $\mathrm{MgO} / \mathrm{Al}_{2} \mathrm{O}_{3}$ showed no trend with values of $0.24,0.21$ and 0.27 , respectively. Among the three slag conditions, the inclusions equilibrated with slag No. 3 with basicity 4.54 had the highest value of $\mathrm{CaO} / \mathrm{Al}_{2} \mathrm{O}_{3}$ and $\mathrm{MgO} / \mathrm{Al}_{2} \mathrm{O}_{3}$.

Wang et al. [9] also investigated the effect of slag basicity on inclusions by slag-metal reactions in laboratory; the steel used in experiments was high-strength alloying steel (0.35C-0.24Si-0.62Mn-1.13Cr-0.23Mo). The average $\mathrm{CaO}$ content in inclusions increased and $\mathrm{Al}_{2} \mathrm{O}_{3}$ content decreased, and the ratio $\mathrm{CaO} / \mathrm{Al}_{2} \mathrm{O}_{3}$ increased with increasing $(\mathrm{CaO}+\mathrm{MgO}) / \mathrm{SiO}_{2}$ in slag, while the ratio $\mathrm{MgO} / \mathrm{Al}_{2} \mathrm{O}_{3}$ in inclusions showed no trend, as shown in Figure 6.

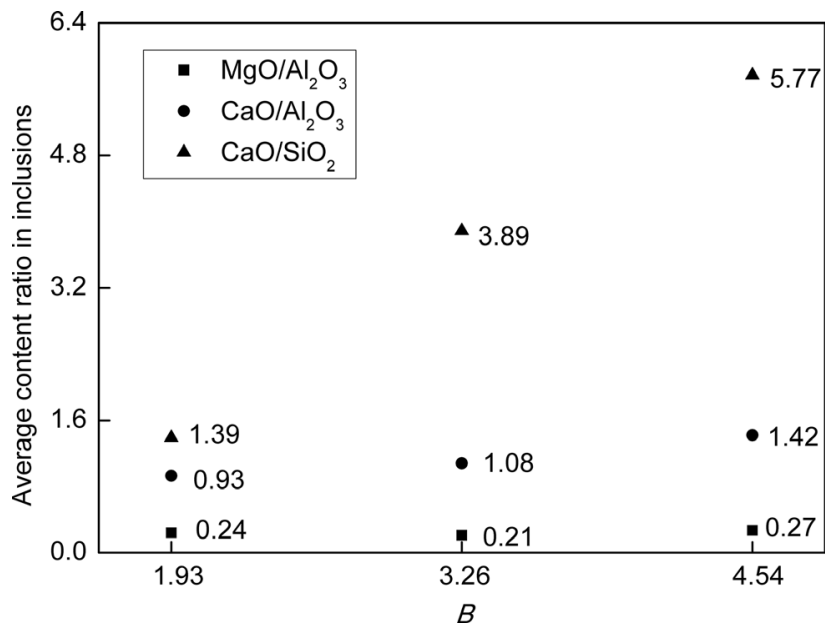

Figure 5: The relationship between average content ratio of inclusions and slag basicity. 


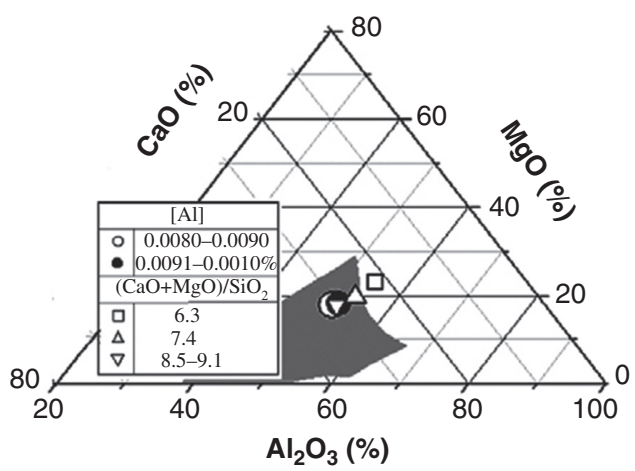

Figure 6: Influences of [Al] and slag basicity on composition of the inclusions [9].

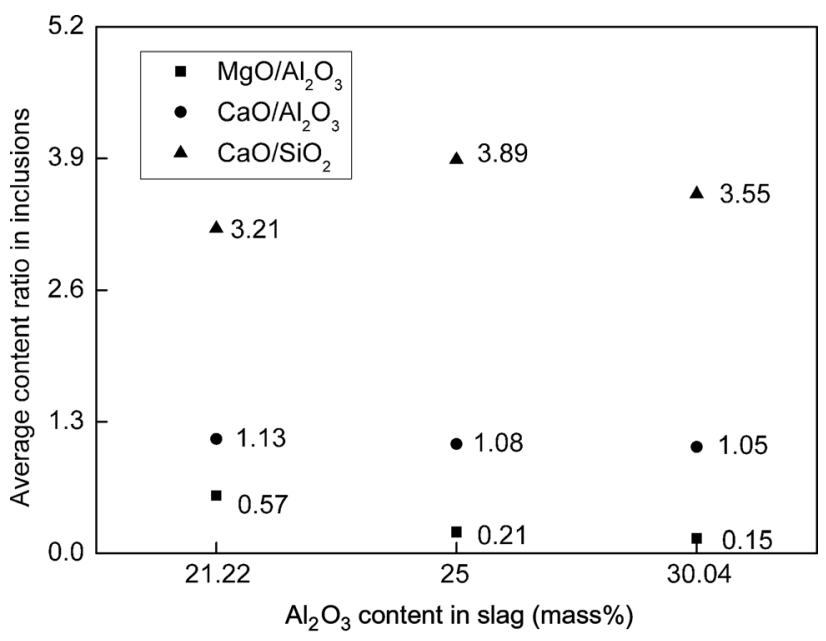

Figure 7: The relationship between average content ratio of inclusions and $\mathrm{Al}_{2} \mathrm{O}_{3}$ content in slag.

\section{Effect of $\mathrm{Al}_{2} \mathrm{O}_{3}$ content in slag on inclusions}

The ratios $\mathrm{CaO} / \mathrm{Al}_{2} \mathrm{O}_{3}, \mathrm{MgO} / \mathrm{Al}_{2} \mathrm{O}_{3}$ and $\mathrm{CaO} / \mathrm{SiO}_{2}$ of inclusions under the slag conditions containing different $\mathrm{Al}_{2} \mathrm{O}_{3}$ content are shown in Figure 7. With decreasing $\mathrm{Al}_{2} \mathrm{O}_{3}$ content in slag but identical slag basicity of 3.3, the $\mathrm{MgO} / \mathrm{Al}_{2} \mathrm{O}_{3}$ of inclusions increased greatly with values of $0.15,0.21$ and $0.57, \mathrm{CaO} / \mathrm{Al}_{2} \mathrm{O}_{3}$ increased a little with values of $1.05,1.08$ and 1.13 and $\mathrm{CaO} / \mathrm{SiO}_{2}$ showed no trend with values of 3.55, 3.89 and 3.21, respectively. Among the three slag conditions, the inclusions equilibrated with slag No. 4 containing about $21 \% \mathrm{Al}_{2} \mathrm{O}_{3}$ had the highest value of $\mathrm{CaO} / \mathrm{Al}_{2} \mathrm{O}_{3}$ and $\mathrm{MgO} / \mathrm{Al}_{2} \mathrm{O}_{3}$.

The effect of $\mathrm{Al}_{2} \mathrm{O}_{3}$ content in slag on inclusions obtained in the present work agrees with the research of Wang et al. [9]. The inclusions in high-strength alloying steels in equilibrium with slag A (6.5 basicity and 41\% $\mathrm{Al}_{2} \mathrm{O}_{3}$ ) and slag $\mathrm{B}\left(5\right.$ basicity and $23 \% \mathrm{Al}_{2} \mathrm{O}_{3}$ ) were investigated by slag-metal reactions in laboratory. The $\mathrm{Al}_{2} \mathrm{O}_{3}$ content in inclusions equilibrated with slag $\mathrm{A}$ was more than that with slag $\mathrm{B}, \mathrm{MgO}$ content was less and the ratio $\mathrm{MgO} / \mathrm{Al}_{2} \mathrm{O}_{3}$ in inclusions was lower, as shown in Figure 8.

The relationship between $\log \left(X_{\mathrm{MgO}} / X_{\mathrm{Al2O}}\right)$ of inclusions and $\log \left(a_{\mathrm{MgO}} / a_{\mathrm{Al2O} 3}\right)$ of slags at $1,873 \mathrm{~K}$ is shown in Figure 9, where $X_{\mathrm{i}}$ is the mole fraction of $i$ in inclusions and $a_{i}$ is the activity of $i$ in slags calculated using thermodynamic software Thermo-Calc. The calculated conditions were as follows: temperature $(T), 1,873 \mathrm{~K}$; pressure (P), 101,325 Pa; $B$, 3.3; MgO, saturated; $\mathrm{Al}_{2} \mathrm{O}_{3}, 21 \%, 25 \%$ and $30 \%$. The $\log \left(X_{\mathrm{MgO}} / X_{\mathrm{Al2O}}\right)$ of inclusions exhibited a linear relation to $\log \left(a_{\mathrm{MgO}} / a_{\mathrm{Al2O}}\right)$ of slags with the slope close to unity. These phenomena could reveal that the slag/metal/inclusion system investigated in the present work was in thermodynamic equilibrium. The results were identical to that of Jiang et al. [15] and Park et al. [17], as shown in Figure 10.

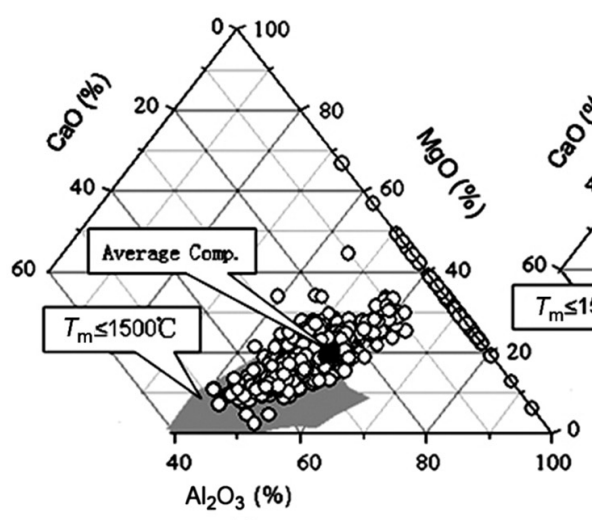

(a)

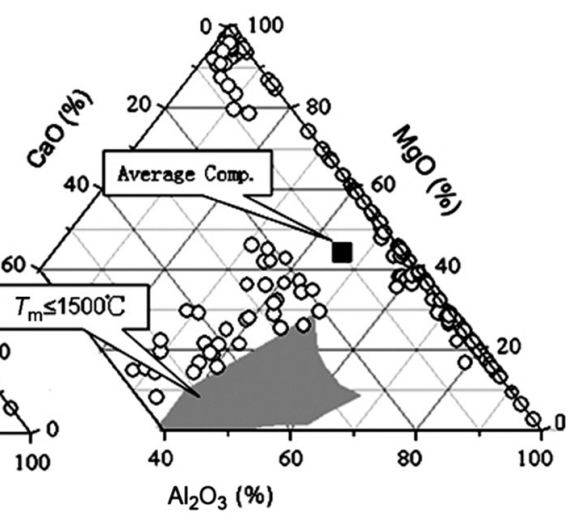

(b)

Figure 8: Effect of slag on composition distribution of the inclusions [9]. (a) Slag A; (b) slag B. 


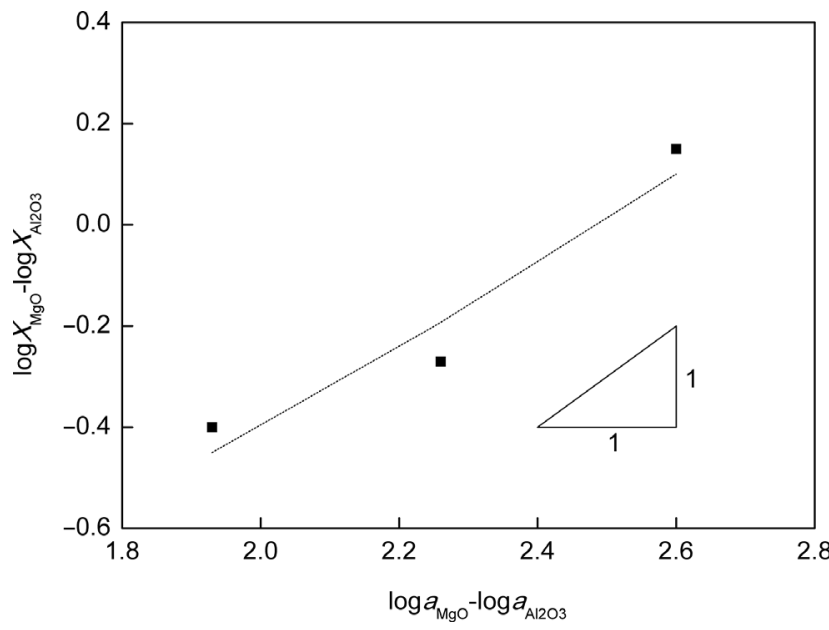

Figure 9: Composition of inclusions, $\log \left(X_{\mathrm{MgO}} / X_{\mathrm{Al} 203}\right)$ as a function of $\log \left(a_{\mathrm{MgO}} / a_{\mathrm{Al203}}\right)$ of slag at $1,873 \mathrm{~K}$.

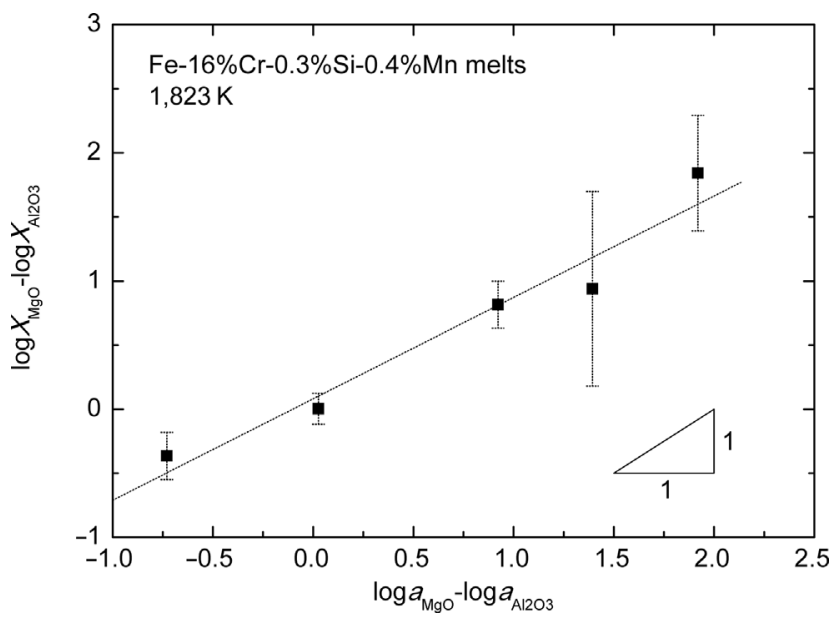

Figure 10: Composition of inclusions, $\log \left(X_{\mathrm{MgO}} / X_{\mathrm{Al203}}\right)$ as a function of $\log \left(a_{\mathrm{MgO}} / a_{\mathrm{Al} 203}\right)$ at $1,823 \mathrm{~K}[17]$.

\section{The method to increase the melting temperature of inclusions}

The liquid zone $(<1,773 \mathrm{~K})$ moved toward the direction of $(\mathrm{CaO}+\mathrm{MgO}) / \mathrm{Al}_{2} \mathrm{O}_{3}$ decreasing with $\mathrm{SiO}_{2}$ content in $\mathrm{CaO}$ $\mathrm{MgO}-\mathrm{Al}_{2} \mathrm{O}_{3}-\mathrm{SiO}_{2}$ system decreasing, as shown in Figure 3. For the present work, the $\mathrm{SiO}_{2}$ content in inclusions was mainly influenced by slag basicity. For example, the basicity of slag No. 1-5 after equilibrium was 1.93, 3.26, 4.54, 3.27 and 3.31, and the average $\mathrm{SiO}_{2}$ content in inclusions was approximately $22 \%, 11 \%, 9 \%, 11 \%$ and $11 \%$, respectively. The $\mathrm{CaO} / \mathrm{Al}_{2} \mathrm{O}_{3}$ in inclusions was more than 1 when slag basicity was $\geq 3.26$ as shown in Figure 5. For HSLA steel, the slag basicity should not be low to make high efficient desulfurization. So to make the inclusions out of the liquid region $(<1,773 \mathrm{~K})$, the inclusions should move toward the direction of $(\mathrm{CaO}+\mathrm{MgO}) /$ $\mathrm{Al}_{2} \mathrm{O}_{3}$ increasing, that is to say, the ratios $\mathrm{CaO} / \mathrm{Al}_{2} \mathrm{O}_{3}$, $\mathrm{MgO} / \mathrm{Al}_{2} \mathrm{O}_{3}$ and $(\mathrm{CaO}+\mathrm{MgO}) / \mathrm{Al}_{2} \mathrm{O}_{3}$ of inclusions should be increased.

The ratios $\mathrm{CaO} / \mathrm{Al}_{2} \mathrm{O}_{3}, \mathrm{MgO} / \mathrm{Al}_{2} \mathrm{O}_{3}$ and $(\mathrm{CaO}+\mathrm{MgO}) /$ $\mathrm{Al}_{2} \mathrm{O}_{3}$ of inclusions under the five slag conditions are shown in Figure 11. The inclusions in equilibrium with slag No. 4 had the highest $(\mathrm{CaO}+\mathrm{MgO}) / \mathrm{Al}_{2} \mathrm{O}_{3}$ and $\mathrm{MgO} /$ $\mathrm{Al}_{2} \mathrm{O}_{3}$ and the second highest $\mathrm{CaO} / \mathrm{Al}_{2} \mathrm{O}_{3}$, then lots of inclusions were solid ( $\geq 1,773 \mathrm{~K})$. The inclusions in equilibrium with slag No. 3 had the second highest $(\mathrm{CaO}+\mathrm{MgO}) / \mathrm{Al}_{2} \mathrm{O}_{3}$ and $\mathrm{MgO} / \mathrm{Al}_{2} \mathrm{O}_{3}$ and the highest $\mathrm{CaO} /$ $\mathrm{Al}_{2} \mathrm{O}_{3}$, then part of inclusions were solid $(\geq 1,773 \mathrm{~K})$. The inclusions in equilibrium with slag No. 12 and 5 had relatively lower $(\mathrm{CaO}+\mathrm{MgO}) / \mathrm{Al}_{2} \mathrm{O}_{3}, \quad \mathrm{MgO} / \mathrm{Al}_{2} \mathrm{O}_{3}$ and $\mathrm{CaO} / \mathrm{Al}_{2} \mathrm{O}_{3}$, then most inclusions were liquid $(<1,773 \mathrm{~K})$.

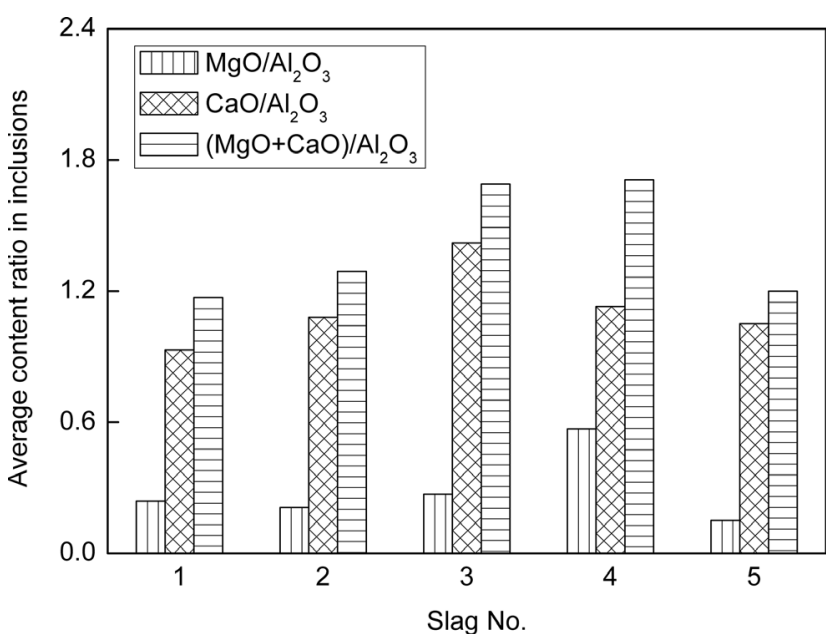

Figure 11: The average content ratio of inclusions under the five slag conditions.

As shown in Figures 5, 7 and 11, the $\mathrm{CaO} / \mathrm{Al}_{2} \mathrm{O}_{3}$ of inclusions increased with the rise of slag basicity and the $\mathrm{MgO} / \mathrm{Al}_{2} \mathrm{O}_{3}$ increased with $\mathrm{Al}_{2} \mathrm{O}_{3}$ in slag decreasing, and the $\mathrm{CaO} / \mathrm{Al}_{2} \mathrm{O}_{3}$ was mainly influenced by slag basicity and the $\mathrm{MgO} / \mathrm{Al}_{2} \mathrm{O}_{3}$ was influenced mainly by $\mathrm{Al}_{2} \mathrm{O}_{3}$ content in slag. So the values of $\mathrm{CaO} / \mathrm{Al}_{2} \mathrm{O}_{3}, \mathrm{MgO} / \mathrm{Al}_{2} \mathrm{O}_{3}$ and $(\mathrm{CaO}+\mathrm{MgO}) / \mathrm{Al}_{2} \mathrm{O}_{3}$ of inclusions should be enhanced by increasing basicity and decreasing $\mathrm{Al}_{2} \mathrm{O}_{3}$ content in slag properly to make the inclusions solid ( $\geq 1,773 \mathrm{~K})$.

\section{Conclusions}

Laboratory-scale experiments as well as thermodynamic calculations have been done to investigate the effect of 
refining slags ( $\left.B: 2-5, \mathrm{Al}_{2} \mathrm{O}_{3}: 20 \%-30 \%\right)$ on oxide inclusions in HSLA steel. The following conclusions were obtained:

1) Oxide inclusions in equilibrium with the slags were mainly quasi-spherical $\mathrm{CaO}-\mathrm{MgO}-\mathrm{Al}_{2} \mathrm{O}_{3}-\mathrm{SiO}_{2}$ system with size less than $5 \mu \mathrm{m}$.

2) The average content ratios, $\mathrm{CaO} / \mathrm{Al}_{2} \mathrm{O}_{3}$ and $\mathrm{CaO} / \mathrm{SiO}_{2}$ of inclusions, increased with the rise of slag basicity when $\mathrm{Al}_{2} \mathrm{O}_{3}$ content in slag was around $25 \%$. The $\mathrm{MgO} / \mathrm{Al}_{2} \mathrm{O}_{3}$ and $\mathrm{CaO} / \mathrm{Al}_{2} \mathrm{O}_{3}$ of inclusions increased with $\mathrm{Al}_{2} \mathrm{O}_{3}$ content in slag decreasing when basicity was around 3.3. The $\mathrm{MgO} / \mathrm{Al}_{2} \mathrm{O}_{3}$ of inclusions was influenced mainly by $\mathrm{Al}_{2} \mathrm{O}_{3}$ content in slag and the $\mathrm{CaO} / \mathrm{Al}_{2} \mathrm{O}_{3}$ was influenced mainly by slag basicity.

3) The inclusions under slag No. 3 and 4 conditions had relatively higher values of $(\mathrm{CaO}+\mathrm{MgO}) / \mathrm{Al}_{2} \mathrm{O}_{3}, \mathrm{MgO} /$ $\mathrm{Al}_{2} \mathrm{O}_{3}$, and $\mathrm{CaO} / \mathrm{Al}_{2} \mathrm{O}_{3}$. As a result, lots of inclusions were solid $(\geq 1,773 \mathrm{~K})$. While the inclusions under slag No. 1, 2 and 5 conditions had relatively lower values of $(\mathrm{CaO}+\mathrm{MgO}) / \mathrm{Al}_{2} \mathrm{O}_{3}, \mathrm{MgO} / \mathrm{Al}_{2} \mathrm{O}_{3}$ and $\mathrm{CaO} /$ $\mathrm{Al}_{2} \mathrm{O}_{3}$, most inclusions were liquid $(<1,773 \mathrm{~K})$.

4) To make the inclusions out of relative lower melting region $(<1,773 \mathrm{~K})$, the ratios, $\mathrm{CaO} / \mathrm{Al}_{2} \mathrm{O}_{3}, \mathrm{MgO} / \mathrm{Al}_{2} \mathrm{O}_{3}$ and $(\mathrm{CaO}+\mathrm{MgO}) / \mathrm{Al}_{2} \mathrm{O}_{3}$ of inclusions, should be enhanced by increasing basicity and decreasing $\mathrm{Al}_{2} \mathrm{O}_{3}$ content in slag properly.

Funding: The authors are grateful to the team of National Basic Research Program of China (No. 2010CB630806) and State Key Laboratory of Advanced Metallurgy (USTB) (No. 41603015) for financial support.

\section{References}

1. Wang XH. Proceedings of national steelmaking-continuous casting technology meeting, July 30-August 1, 2008, Hangzhou, The Chinese Society for Metals, 2008.

2. Ogura Y, Kikuchi Y, Hasegawa T, et al. Tetsu-to-Hagane 1986;72:1309-15.

3. Bannenberg N, Bergmann B, Gaye H. Steel Res 1992;63:431-7.

4. Chen WJ, Chen JS, Zheng JZ. CSM 2009 annual meeting proceedings, November 11-13, 2009, Beijing, The Chinese Society for Metals, 2009.

5. Son JH, Jung IH, Jung SM, et al. ISIJ Int 2008;48:1542-51.

6. Li Q, Wang XH, Li HB, et al. J Iron Steel Res Int 2011;18:563-6.

7. Wang XH, Li XG, Li Q, et al. Steel Res Int 2014;85:155-63.

8. Zhu GS, Li HB, Li BH, et al. Proceedings of the 5th international congress on the science and technology of steelmaking, October 1-3, 2012, Dresden, ENGICOM GmbH, 2012.

9. Wang $\mathrm{XH}$, Chen $\mathrm{B}$, Jiang $\mathrm{M}$, et al. Proceedings of the 4th international congress on the science and technology of steelmaking, October 6-8, 2008, Gifu, The Iron and Steel Institute of Japan, 2008.

10. Yu HX, Wang XH, Zhang J, et al. J Iron Steel Res Int 2011;18:6-11.

11. Wang LF, Zhang JM, Wang XH, et al. J Univ Sci Technol B 2004;26:26-9.

12. Jiang ZH, Li Y, Jiang MF. CSM 2003 annual meeting proceedings, October 28-30, 2003, Beijing, The Chinese Society for Metals, 2003.

13. Chen SH, Jiang M, He XF, et al. J Miner Metall Mater 2012;19:490-8.

14. Chen B. Investigation on liquid steel-slag equilibrium and the non-metallic inclusions in alloying structural steels [Dissertation for Doctor degree]. Beijing: University of Science and Technology Beijing, 2008.

15. Jiang M, Wang XH, Chen B, et al. ISIJ Int 2008;48:885-90.

16. Wang XH, Jiang M, Chen B, et al. Sci China Technol Sci 2012;55:1863-72.

17. Park JH, Kim DS. Metall Mater Trans B 2005;36B:495-502. 